\title{
Higher plant diversity enhances soil stability in disturbed alpine ecosystems
}

\author{
Mandy Pohl • Dominik Alig • Christian Körner • \\ Christian Rixen
}

Received: 11 September 2008 / Accepted: 20 January 2009 /Published online: 4 February 2009

(C) Springer Science + Business Media B.V. 2009

\begin{abstract}
Plant diversity is hypothesised to increase soil stability by increasing the diversity of root types. To test this hypothesis, we took soil cores from machine-graded ski slopes and from the adjacent undisturbed vegetation as a control. We quantified aggregate stability as an indicator for soil stability in relation to (1) abiotic soil properties, (2) above-ground vegetation characteristics and (3) root parameters. From the three groups of variables, the number of plant species, root density (RD) and sand content showed the highest correlation with soil aggregate stability and explained $54 \%$ of its variance. In variance partitioning, the number of plant species was the most relevant factor explaining $19 \%$ of the variance in aggregate stability. Further, it explained another $11 \%$ through shared effects with RD and sand content. An additional $8 \%$ was explained through the shared influence with sand content. Plant species showing
\end{abstract}

Responsible Editor: Alexia Stokes.

M. Pohl $(\varangle) \cdot$ D. Alig $\cdot$ C. Rixen

WSL Institute for Snow and Avalanche Research SLF, Unit Ecosystem Boundaries, Alpine Ecosystems,

Flüelastrasse 11,

7260 Davos Dorf, Switzerland

e-mail: pohl@slf.ch

C. Körner

Institute of Botany, University of Basel,

Schönbeinstrasse 6,

4056 Basel, Switzerland the highest correlation with overall diversity were from different functional groups (grasses, forbs and shrubs), meaning that beneficial effects can not only be assigned to one specific functional group, but to the combination of several groups. Our data demonstrate the positive effect of plant diversity on aggregate stability. We suggest that high plant diversity is one of the most relevant factors for enhancing soil stability at disturbed sites at high elevation.

Keywords Aggregate stability · Dwarf shrubs · Erosion control · Forbs $\cdot$ Grasses $\cdot$ Roots

\section{Introduction}

Soil erosion is one of the major and most widespread forms of land degradation (Zuazo and Pleguezuelo 2008). A functional plant cover provides soil stability and is especially important in alpine ecosystems. Steep slopes above the timberline are prone to erosion when the natural vegetation cover (Van Ommeren 2001; Wipf et al. 2005) and the upper soil layer (Barni et al. 2007; Delgado et al. 2007; Gros et al. 2004) are damaged. Such damage is commonplace, e.g. after machine-grading on ski slopes where rocks are removed and rough soil surfaces are levelled (Rixen et al. 2003, 2004; Urbanska 1995). Subsequently, high proportions of bare ground are prone to loss of soil particles, plant seeds, nutrients and organic matter 
when intense rainfall occurs (Isselin-Nondedeu and Bédécarrats 2007; Zuazo and Pleguezuelo 2008). Recolonization of such damaged sites by plants is difficult because the growing conditions during the short growing season are harsh and plant growth is slow (Cammeraat et al. 2005; Chambers 1993; Urbanska 1997; Urbanska and Fattorini 1998; Wipf et al. 2005). These conditions often result in long-term decline in soil quality and plant species diversity. Therefore, understanding soil stability and effective erosion control is key in preventing soil degradation in alpine ecosystems. A simple and informative method for understanding the resistance of soil to erosion in the field is measuring soil aggregate stability. Aggregate stability is a relevant indicator for soil stability because it reflects several other important soil characteristics and because it quantifies the topsoil content in stable aggregates (Barthès and Roose 2002; Bird et al. 2007; Frei et al. 2003; Shinjo et al. 1999).

The mechanisms by which vegetation stabilises the ground are manifold. The above-ground components of the vegetation increase the surface roughness and act as a wind break and sediment trap (Gray and Sotir 1996), and the below-ground root systems form anchors that stabilise loose soil (Gyssels and Poesen 2003; Mattia et al. 2005; Nilaweera and Nutalaya 1999). The roots play an essential role in shallow slope stabilisation by controlling both hydrological and mechanical properties (De Baets et al. 2006; Gray and Sotir 1996; Gyssels and Poesen 2003; Mattia et al. 2005; Nilaweera and Nutalaya 1999; Reubens et al. 2007). Roots affect important soil properties such as aggregate stability, infiltration capacity, soil bulk density, soil texture, organic and chemical content and shear strength (Miller and Jastrow 1990; Reubens et al. 2007). They increase the surface roughness and the infiltration capacity by creating soil macro-pores and therefore reduce the volume and velocity of the surface runoff. Dense roots form a network in the ground and provide substantial soil cohesion by binding soil particles down to the rooting depth of the vegetation (Gyssels et al. 2005). Roots and organic matter physically bind soil particles and therefore build mechanical barriers for soil and water movement. Soil micro-organisms feed on roots and in turn produce further organic bindings (Gyssels and Poesen 2003). These bindings increase the aggregation of soil particles and are thus able to reduce soil erosion. To investigate root effects on erosion, root density ( $R D$, in kilograms per cubic meter) and root length density (in kilometers per cubic meter) are generally used as root parameters (Gyssels et al. 2005). Root diameter is a further important variable, as the effect of $\mathrm{RD}$ in reducing erosion decreases with increasing root diameter (De Baets et al. 2007a, b).

Biodiversity has positive effects on ecosystem functioning such as light harvesting (Spehn et al. 2000) or soil nutrient foraging (Niklaus et al. 2001). Higher species diversity may lead to higher biomass and retention of ecosystem integrity under severe stress, given the greater likelihood of the presence of tolerant taxa ('insurance' hypothesis, e.g. Kahmen et al. 2005). However, only few studies have investigated root characteristics at high plant diversity (but see Scherer-Lorenzen et al. 2003; Spehn et al. 2005). Scott (1998) and Miller and Jastrow (1990) reported positive plant species effects on soil aggregation; however, to our knowledge, no research has yet addressed the relationship between plant diversity, root characteristics and soil stability in steep mountain areas. Körner and Spehn (2002) have suggested that vegetation with diverse growth forms is more effective at stabilizing slopes than uniform vegetation with few species. Further Reubens et al. (2007) proposed that a combination of shallow but dense root networks of fine roots and deeply penetrating coarse roots might be most beneficial to control soil erosion processes. This combination of growth forms is most likely to occur in a mixture of different plant species or functional groups providing a variety of root types, each performing specific functions. However, only few studies have actually investigated the effects of below-ground structures and the crucial role of roots for soil stability in alpine ecosystems.

In this paper, we investigate the relationships between soil stability, root characteristics and plant diversity by assessing aggregate stability on disturbed soils. Abiotic soil properties, above-ground vegetation characteristics and root parameters were determined on machine-graded ski slopes. Sites on machinegraded ski slopes were selected for this study because of their sparse vegetation cover and erosion-prone soils. We hypothesised that, beyond vegetation cover and soil properties, plant diversity plays an important role in soil aggregate stability due to a higher number of root types. 


\section{Material and methods}

Study sites and experimental design

The study was conducted in summer 2007 in the ski resorts Jakobshorn in Davos ( 46 $^{\circ} 46^{\prime}$, E 9 $9^{\circ} 50^{\prime}$ ), Lenzerheide (N 46 $46^{\prime}$, E $9^{\circ} 35^{\prime}$ ) and in Flims-Laax (N 46 50', E $9^{\circ} 10^{\prime}$ ) in the Central Eastern Alps (Canton of Grisons, Switzerland). Mean air temperature is $-7^{\circ} \mathrm{C}$ in January and $+12^{\circ} \mathrm{C}$ in July, and annual mean precipitation is $1,007 \mathrm{~mm} /$ year (Davos). The study sites are located above the timberline on an altitudinal gradient from 1,953 to 2,582 masl. (Table 1) and are covered with snow from the beginning of November until the end of May. The most common vegetation types are alpine pastures on mostly acidic bedrock with Carex curvula, Cetraria islandica, Cladonia spp., Helictotrichon versicolor, Homogyne alpina, Leontodon helveticus, Ligusticum mutellina and Vaccinium myrtillus as dominant species. The study sites were chosen on two machine-graded ski slopes per ski resort, one with artificial snow production and one with natural snow. At the Lenzerheide ski resort, an additional ski slope with natural snow was selected. The sites had high proportions of bare ground and were prone to increased surface runoff and erosion during heavy rain events. Along each ski slope, six plots on and six control plots adjacent to each ski slope were randomly selected. We determined plots by walking along a transect line on the ski slopes. At regular intervals (20-
$180 \mathrm{~m}$ depending on the site) we chose the plots by throwing a frame. Control plots were selected adjacent to the ski slope using the same procedure. Plots were $20 \mathrm{~cm}$ in diameter $\left(314 \mathrm{~cm}^{2}\right)$; we chose a small plot size to limit the influence of spatial heterogeneity and to increase the total sample size $(n=84)$.

\section{Measurements}

\section{Abiotic soil properties}

Two soil samples were taken from each plot using a $30 \mathrm{~cm}$-long cylindrical corer $(d=5 \mathrm{~cm})$. The soil samples were cold stored at $4{ }^{\circ} \mathrm{C}$ and analysed within 14 days. One of the two soil cores was used to determine gravimetric soil moisture (in grams per gram) and bulk density (grams per cubic centimeter) $(0-20 \mathrm{~cm}$ soil depth) by oven drying at $105^{\circ} \mathrm{C}$ for $48 \mathrm{~h}$. With the second soil core, the stability of soil aggregates (in grams per gram) and soil texture were evaluated. To quantify the stability of soil aggregates, we used a modified wet sieving method after Frei et al. (2003). Therefore, the topmost 0 to $10 \mathrm{~cm}$ of the soil samples were placed on a $20 \mathrm{~mm}$ mesh-sieve and flooded with local spring water, the quality of which is close to precipitation water (conductivity $\sigma<100 \mu \mathrm{S} \mathrm{cm} \mathrm{cm}^{-1}$, water hardness $<4{ }^{\circ} \mathrm{f}$ ). After $5 \mathrm{~min}$, the water was drained and the remaining soil from the sieve was removed. The roots were then separated from the soil (see section on above- and below-ground vegetation

Table 1 Characteristics of plots on ski slopes and in adjacent control plots at the three study sites

\begin{tabular}{|c|c|c|c|c|c|c|}
\hline Ski resort & Number of ski slope & Type of snow & Elevation (masl) & Inclination $\left(^{\circ}\right)$ & Artificial snow since & Machine-graded in \\
\hline \multirow[t]{2}{*}{ Davos Jakobshorn } & 5 & Natural & $2,302-2,436$ & $12-25$ & - & 1965 \\
\hline & Control & - & $2,317-2,438$ & $10-26$ & - & - \\
\hline \multirow[t]{2}{*}{ Davos Jakobshorn } & 8 & Artificial & $2,300-2,471$ & $18-20$ & 1994 & 1965 \\
\hline & Control & - & $2,312-2,492$ & $15-25$ & - & - \\
\hline \multirow[t]{2}{*}{ Flims/Laax } & 41 & Natural & $2,389-2,435$ & $14-20$ & - & 1973 \\
\hline & Control & - & $2,383-2,439$ & $20-25$ & - & - \\
\hline \multirow[t]{2}{*}{ Flims/Laax } & 66 & Artificial & $2,119-2,199$ & $10-20$ & 1993 & 1970 \\
\hline & Control & - & $2,102-2,186$ & $10-24$ & - & - \\
\hline \multirow[t]{2}{*}{ Lenzerheide } & 2,4 & Natural & $2,427-2,582$ & $15-25$ & - & 1993, 1988 \\
\hline & Control & - & $2,431-2,574$ & $13-32$ & - & - \\
\hline \multirow[t]{2}{*}{ Lenzerheide } & 5 & Artificial & $2,164-2,249$ & $20-25$ & na & 1993 \\
\hline & Control & - & $2,162-2,252$ & $15-26$ & - & - \\
\hline
\end{tabular}

Along each ski slope, six plots on and six control plots adjacent to each ski slope were selected. In each plot, two soil cores were sampled. Data are minimum and maximum values

na not available 
characteristics). The soil trapped by the sieve and that which passed through were oven-dried separately at $105^{\circ} \mathrm{C}$ for $24 \mathrm{~h}$ and weighted. Stones $>20 \mathrm{~mm}$ were weighted separately. Stable aggregates were represented by the proportion of the soil that did not pass through the $20 \mathrm{~mm}$ sieve over the entire soil sample minus the stones $>20 \mathrm{~mm}$. Organic matter in all samples was determined in duplicates by combustion at $550^{\circ} \mathrm{C}$ for at least $2 \mathrm{~h}$ (Bisutti et al. 2004). Particle size distribution was determined (1) by sieving the coarse fractions (gravel, $>2 \mathrm{~mm}$ ) and (2) by sedimentation for determining proportions of silt (0.05$0.002 \mathrm{~mm})$ and clay $(<0.002 \mathrm{~mm})$ with the pipette analysis in duplicates. The proportion of sand (2$0.05 \mathrm{~mm}$ ) was calculated thereafter (Gee and Bauder 1986). Soil pH of each plot was measured in the field ( $\mathrm{pH}$-field kit Hellige, VWR International AG, Dietikon, Switzerland).

\section{Above- and below ground vegetation characteristics}

In each plot, we recorded the presence of all plant species and cover percentage of grasses, forbs, shrubs, mosses and lichens, and the cover percentage of the un-vegetated ground. For each plot on the ski slopes, we calculated the Shannon-index of diversity as $H=-\Sigma P_{i} \ln P_{i}$, where $P_{i}$ is the abundance of species $i$.

Root parameters were determined for plots on the ski slopes only. Roots were removed from soil (see section on abiotic soil properties for sampling strategy), washed and stored in $15 \%$ ethanol-water at $4{ }^{\circ} \mathrm{C}$ until processing. Total root length was determined using the image analysing software WinRhizo (Regent Instrument, Quebec, Canada). Root length density RLD (in kilometers per cubic meter) was calculated by dividing the mean length of the roots by the volume of the corresponding soil cylinder. Root length density distribution was determined within four root diameter classes: very fine roots $(<0.5 \mathrm{~mm})$, fine roots $(0.5-1.0 \mathrm{~mm})$, fibrous roots $(1.0-1.5 \mathrm{~mm})$, and coarse roots $(>1.5 \mathrm{~mm})$. Root density RD (in kilograms per cubic meter) was obtained by dividing the dry mass of roots by the volume of the soil cylinder.

Statistical analysis

Differences between plots on ski slopes and adjacent control plots were analysed with two-way Analysis of
Variance (ANOVA) with the fixed factors 'ski slope' (plot on the ski slope or control) and 'snow type' (natural or artificial snow) and the interaction 'ski slope $\times$ snow type'. Elevation was included as a covariate in all analyses. We also tested our statistical model with the covariate soil moisture, but the results were not significantly different from those that we present now. Therefore, we present the statistical analysis with only elevation as a covariate. If necessary to meet the assumptions of ANOVA, variables were transformed prior to analysis using a square-root transformation (Shannon-index, soil moisture, RLD and RD), arcsine square root transformation (vegetation cover, $\mathrm{pH}$, aggregate stability, gravel- and sand content) or log transformation (silt and clay content). A LSD test was used for pair-wise comparisons to distinguish significant differences between means at $P<0.05$. Simple linear regression was employed to identify three variables for subsequent multiple regression, from the variable groups 'abiotic soil properties', 'above-vegetation characteristics' and 'root parameters', which had the strongest influence on aggregate stability. The variables number of plant species, root density and sand content were chosen according to the best fit regression models. Sand content showed a slightly weaker relationship with aggregate stability than gravel content (Table 5), but was preferred for the subsequent analyses because the gravel fraction $(>20 \mathrm{~mm})$ does not contribute to mechanisms involving aggregate formation. To understand the interactions between the variables and how much variation can be explained by means of known variables, variance partitioning was used to determine the unique and the shared effects of the explanatory variables (Borcard et al. 1992; Roy et al. 2004). Therefore, multivariate stepwise analysis was used to decompose the total sum of squares (Ss) of the dependent variable (aggregate stability) into components of each explanatory variable and an unexplained error term (Table 6). We used logistic regression and chi-square tests to test (1) which plant species were significantly more frequent in plots on the ski slopes vs. control plots or on ski slopes with artificial vs. natural snow and (2) if a plant species occurrence (of the 70 plant species that were present in at least $5 \%$ of all plots) was significantly related to the plant species richness in the plots on ski slopes. All analyses were carried out in SPSS 15.0. 


\section{Results}

Abiotic soil properties

Soil texture in the topmost $10 \mathrm{~cm}$ was loamy sand in all plots on the ski slopes and in the control plots. Particle size distributions did not show significant variation in the content of gravel, sand, silt and clay between plots on ski slopes and control plots (Table 2). Bare ground was higher in plots on ski slopes compared to adjacent control plots $\left(6 \%\right.$ vs. $1 \%$ bare ground, $F_{(1,79)}=7.37$; $P<0.01$; Table 2). Organic matter content and aggregate stability did not differ significantly between plots on the ski slopes and control plots. Soil moisture was significantly lower $\left(F_{(1,78)}=23.15, P<0.001\right)$ and bulk density was higher $\left(F_{(1,79)}=12.31, P<0.001\right)$ on ski slopes compared to adjacent control plots. Of all abiotic soil properties, only sand content was marginally influenced by elevation $\left(F_{(1,78)}=3.53, P<0.1\right)$.

Ski slopes with artificial snow did not differ from those with natural snow; only aggregate stability was marginally lower compared to adjacent control plots (LSD test, $P<0.1$ )

Above-ground vegetation characteristics

The number of plant species was significantly lower on ski slopes compared to control plots (8.4 vs. 11.5 species, $F_{(1,79)}=19.07, P<0.001$ ) (Table 3). Vegetation cover showed a significant decrease of $21 \%$ in plots on ski slopes compared to control plots $\left(F_{(1,79)}=17.62\right.$,
$P<0.001)$ and decreased with increasing elevation $\left(F_{(1,39)}=11.10, P<0.01\right)$. Grass and forb cover did not differ significantly between ski slopes and control plots, but there was a shift of plant species within grasses and forbs on ski slopes compared to control plots. The grass Festuca violacea was significantly more frequent on ski slopes $\left(\chi^{2}\right.$-test, $\left.P<0.05\right)$, while Carex curvula and Helictotrichon versicolor were more common in control plots $\left(\chi^{2}\right.$-test, $P<0.1$ and $P<0.05)$. The forb Homogyne alpina was significantly less abundant on ski slopes ( $\chi^{2}$-test, $P<0.001$ ), whereas Achillea millefolium was more frequent on ski slopes compared to control plots $\left(\chi^{2}\right.$-test, $\left.P<0.001\right)$. The shrub cover was significantly lower on ski slopes $(2 \%$ vs. $16 \%$ cover, $\left.F_{(1,79)}=29.81, P<0.001\right)$ and was affected by elevation $\left(F_{(1,79)}=5.67, P<0.05\right)$, e.g. the shrubs Loiseleuria procumbens and Vaccinium vitisidaea were less frequent on ski slopes $\left(\chi^{2}\right.$-test, $P<0.05)$. The lichen cover was also significantly reduced on ski slopes ( $3 \%$ vs. $9 \%$ cover, $F_{(1,79)}=$ 14.20; $P<0.001)$, e.g. lichens of the genus Cladonia $\left(\chi^{2}\right.$-test, $\left.P<0.001\right)$. In contrast, the moss Sanionia uncinata was more frequent on ski slopes than in control plots $\left(\chi^{2}\right.$-test, $\left.P<0.05\right)$.

Artificial snow had no significant influence on the number of plant species and vegetation cover, but the cover of moss and lichen were significantly lower on slopes with artificial snow (moss cover: $F_{(1,79)}=15.79$, $P<0.001$ and lichen cover: $\left.F_{(1,79)}=8.22, P<0.01\right)$. The grass species Poa alpina, Luzula lutea (both $\chi^{2}-$ test, $P<0.01)$ and Agrostis rupestris $(P<0.05)$ and the

Table 2 Soil properties in plots on ski slopes with either natural or artificial snow and adjacent control plots $(n=84)$

\begin{tabular}{|c|c|c|c|c|}
\hline \multirow[t]{2}{*}{ Soil properties } & \multicolumn{2}{|l|}{ Natural snow } & \multicolumn{2}{|l|}{ Artificial snow } \\
\hline & Ski slope $(n=24)$ & Control $(n=24)$ & Ski slope $(n=18)$ & Control $(n=18)$ \\
\hline Bare ground (\%) & $4.0 \pm 1.9 \mathrm{ab}$ & $0.6 \pm 0.5 \mathrm{a}$ & $7.9 \pm 2.9 b$ & $2.2 \pm 1.9 \mathrm{a}$ \\
\hline Gravel (wt. $\%>2 \mathrm{~mm}$ whole soil) & $56.8 \pm 2.6 b$ & $52.1 \pm 4.0 \mathrm{~b}$ & $50.7 \pm 4.8 \mathrm{ab}$ & $41.0 \pm 5.6 \mathrm{a}$ \\
\hline Sand (wt. $\%<2 \mathrm{~mm}$ ) & $60.5 \pm 2.7$ & $61.9 \pm 2.3$ & $59.3 \pm 3.8$ & $57.4 \pm 3.7$ \\
\hline Silt (wt. $\%<2 \mathrm{~mm}$ ) & $30.2 \pm 2.2$ & $28.6 \pm 2.3$ & $28.6 \pm 1.7$ & $28.6 \pm 1.9$ \\
\hline Clay (wt.\% <2 mm) & $9.3 \pm 1.5$ & $9.6 \pm 0.9$ & $12.1 \pm 3.1$ & $14.0 \pm 2.9$ \\
\hline Organic matter (wt.\%) & $22.7 \pm 1.4$ & $23.5 \pm 1.1$ & $23.4 \pm 1.4$ & $23.4 \pm 0.9$ \\
\hline Aggregate stability (wt.\%) & $48.2 \pm 6.4$ & $50.8 \pm 6.6$ & $43.6 \pm 6.3$ & $61.7 \pm 7.0$ \\
\hline Bulk density $\left(\mathrm{g} \mathrm{cm}^{-3}\right)$ & $2.0 \pm 0.3 \mathrm{c}$ & $1.6 \pm 0.1 \mathrm{ab}$ & $1.7 \pm 0.2 \mathrm{bc}$ & $1.4 \pm 0.3 \mathrm{a}$ \\
\hline Moisture (wt.\%) & $20.3 \pm 1.8 \mathrm{a}$ & $30.8 \pm 2.4 b$ & $24.5 \pm 2.9 \mathrm{ab}$ & $44.8 \pm 5.2 \mathrm{c}$ \\
\hline $\mathrm{pH}$ & $4.9 \pm 0.2 \mathrm{ab}$ & $5.1 \pm 0.2 b$ & $4.8 \pm 0.1 \mathrm{ab}$ & $4.5 \pm 0.1 \mathrm{a}$ \\
\hline
\end{tabular}

Values are means \pm 1 standard error. Units are in weight percent (calculated from grams per gram $\times 100$ ). Within a row, values that share a common letter do not differ significantly according to one-way ANOVA $(P<0.05)$; other variables did not differ significantly among ski slope types 
Table 3 Above-ground vegetation characteristics in plots on ski slopes with either natural or artificial snow and in adjacent control plots $(n=84)$

\begin{tabular}{|c|c|c|c|c|}
\hline \multirow[t]{2}{*}{ Above-ground vegetation characteristics } & \multicolumn{2}{|l|}{ Natural snow } & \multicolumn{2}{|l|}{ Artificial snow } \\
\hline & Ski slope $(n=24)$ & Control $(n=24)$ & Ski slope $(n=18)$ & Control $(n=18)$ \\
\hline Number of plant species & $8.4 \pm 0.8 \mathrm{a}$ & $11.8 \pm 0.7 b$ & $8.2 \pm 1.0 \mathrm{a}$ & $11.5 \pm 0.4 \mathrm{~b}$ \\
\hline Shannon index & $1.6 \pm 0.1$ & na & $1.6 \pm 0.1$ & na \\
\hline Vegetation cover $(\%)$ & $76.2 \pm 5.4 \mathrm{a}$ & $93.8 \pm 2.3 b$ & $81.8 \pm 6.5 \mathrm{ab}$ & $95.6 \pm 2.2 b$ \\
\hline Grasses & $25.7 \pm 4.0$ & $30.2 \pm 4.8$ & $38.9 \pm 6.7$ & $34.4 \pm 4.8$ \\
\hline Forbs & $27.3 \pm 3.3$ & $24.0 \pm 3.4$ & $30.4 \pm 5.5$ & $21.1 \pm 3.9$ \\
\hline Shrubs & $2.2 \pm 1.7 \mathrm{a}$ & $10.8 \pm 3.0 \mathrm{~b}$ & $1.4 \pm 0.8 \mathrm{a}$ & $21.1 \pm 5.1 \mathrm{c}$ \\
\hline Moss & $13.6 \pm 2.9 \mathrm{a}$ & $9.8 \pm 1.2 \mathrm{ab}$ & $6.4 \pm 1.7 \mathrm{~b}$ & $9.7 \pm 2.1 \mathrm{ab}$ \\
\hline Lichen & $4.0 \pm 1.1 \mathrm{a}$ & $13.1 \pm 3.1 b$ & $1.7 \pm 0.8 \mathrm{a}$ & $5.7 \pm 1.2 \mathrm{ab}$ \\
\hline Crust & $3.8 \pm 2.2$ & $5.2 \pm 2.0$ & $3.9 \pm 1.5$ & $1.7 \pm 1.0$ \\
\hline
\end{tabular}

Values are means \pm 1 standard error. Within a row, values that share a common letter do not differ significantly according to one-way ANOVA $(P<0.05)$; other variables did not differ significantly among ski slope types

na not analysed

forb species Leucanthemopsis alpina and Alchemilla pentaphyllea (both $P<0.05$ ) were significantly more frequent on ski slopes with natural snow than on those with artificial snow. The grass Nardus stricta was more frequent on slopes with artificial snow $(P<0.05)$.

\section{Root parameters}

Root parameters on ski slopes differed to some extent between ski slopes with natural and artificial snow (Table 4). Total root length density (RLD) in the $10 \mathrm{~cm}$ topsoil varied between $427 \mathrm{~km} \mathrm{~m}^{-3}$ on ski slopes with natural snow and $623 \mathrm{~km} \mathrm{~m}^{-3}$ on those with artificial snow. RLD was highest $\left(476 \mathrm{~km} \mathrm{~m}^{-3}=90 \%\right.$

Table 4 Root length density (RLD) and root density in plots on ski slopes with either natural or artificial snow (control data not presented)

\begin{tabular}{lcc}
\hline $\begin{array}{l}\text { Below-ground root } \\
\text { parameters }\end{array}$ & $\begin{array}{l}\text { Natural snow } \\
(n=24)\end{array}$ & $\begin{array}{l}\text { Artificial snow } \\
(n=15)\end{array}$ \\
\hline $\begin{array}{l}\text { Root length density } \\
\left.(\mathrm{km} \mathrm{m})^{-3}\right)\end{array}$ & $427.2 \pm 79.0$ & $623.0 \pm 170.0$ \\
RLD $(0-0.5 \mathrm{~mm})$ & $370.0 \pm 74.0$ & $581.0 \pm 168.0$ \\
RLD $(0.5-1.0 \mathrm{~mm})$ & $45.4 \pm 7.2$ & $38.7 \pm 8.1$ \\
RLD $(1.0-1.5 \mathrm{~mm})$ & $6.2 \pm 1.1 \mathrm{a}$ & $1.9 \pm 0.5 \mathrm{~b}$ \\
RLD $(>1.5 \mathrm{~mm})$ & $5.6 \pm 1.0 \mathrm{a}$ & $1.8 \pm 0.5 \mathrm{~b}$ \\
Root density $\left(\mathrm{kg} \mathrm{m}^{-3}\right)$ & $7.6 \pm 1.3$ & $8.4 \pm 1.6$ \\
\hline
\end{tabular}

Values are means \pm 1 standard error. Within a row, values that share a common letter do not differ significantly according to one-way ANOVA $(P<0.05)$; other variables did not differ significantly among ski slope types of RLD) for very fine roots $(0-0.5 \mathrm{~mm})$ and decreased with increasing root diameter $\left(4 \mathrm{~km} \mathrm{~m}^{-3}=1 \%\right.$ of RLD for coarse roots $>1.5 \mathrm{~mm})$. RLD of fine roots $(0.5-$ $1.0 \mathrm{~mm}$ ) was marginally lower on ski slopes with artificial snow and was significantly lower for fibrous and coarse roots $\left(1.0-1.5 \mathrm{~mm}: F_{(1,35)}=6.54, P<0.05\right.$ and $\left.>1.5 \mathrm{~mm}: F_{(1,35)}=4.98, P<0.05\right)$. Elevation showed a positive effect on the RLD of fibrous and coarse roots $\left(F_{(1,35)}=4.65\right.$ and 6.41, $\left.P<0.05\right)$. The mean RD in the $10 \mathrm{~cm}$ topsoil was $7.6 \mathrm{~kg} \mathrm{~m}^{-3}$ on ski slopes with natural snow and $8.4 \mathrm{~kg} \mathrm{~m}^{-3}$ on those with artificial snow (not significant).

Variables influencing aggregate stability on ski slopes

Aggregate stability on ski slopes was negatively correlated with bare ground, gravel- and sand content and was positively correlated with clay (marginally) and silt content (Table 5, Fig. 1). Aggregate stability was correlated negatively with bulk density and positively with soil moisture. No relationship was found between aggregate stability and the organic matter content.

Aggregate stability on ski slopes showed a linear relationship with the number of plant species, the Shannon-Index of diversity and vegetation cover (Table 5). Of all above-ground vegetation characteristics, aggregate stability showed the highest correlation with the number of plant species $\left(r^{2}=0.36, P<0.001\right.$, Fig. 1). Aggregate stability also correlated positively with forb and shrub cover and marginally with grass cover (Table 5). 
Table 5 Simple linear regression between the aggregate stability on ski slopes and (a) soil properties, (b) above-ground vegetation characteristics and (c) root parameters (controls were not considered here)

\begin{tabular}{|c|c|c|c|}
\hline & \multicolumn{3}{|c|}{ Linear regression } \\
\hline & $F$ & $r^{2}$ & $P$ \\
\hline \multicolumn{4}{|l|}{ (a) Soil properties } \\
\hline Bare ground $(\%)$ & 8.979 & 0.183 & $* *$ \\
\hline Gravel (wt.\% >2 mm) & 15.351 & 0.282 & $* * *$ \\
\hline Sand (wt. $\%<2 \mathrm{~mm}$ ) & 9.936 & 0.271 & $* *$ \\
\hline Silt (wt. $\%<2 \mathrm{~mm}$ ) & 12.193 & 0.238 & $* *$ \\
\hline Clay (wt. $\%<2 \mathrm{~mm}$ ) & 3.049 & 0.073 & $(*)$ \\
\hline Organic matter (wt.\%) & 0.604 & 0.015 & ns \\
\hline Bulk density $\left(\mathrm{g} \mathrm{cm}^{-3}\right)$ & 11.424 & 0.222 & $* *$ \\
\hline Moisture (wt.\%) & 12.762 & 0.247 & $* *$ \\
\hline $\mathrm{pH}$ & 0.076 & 0.002 & ns \\
\hline \multicolumn{4}{|l|}{$\begin{array}{l}\text { (b) Above-ground vegetation } \\
\text { characteristics }\end{array}$} \\
\hline Number of plant species & 22.096 & 0.356 & $* * *$ \\
\hline Shannon index & 16.280 & 0.289 & $* * *$ \\
\hline Vegetation cover $(\%)$ & 17.211 & 0.139 & $* * *$ \\
\hline Grasses & 3.373 & 0.078 & $(*)$ \\
\hline Forbs & 12.314 & 0.235 & $*$ \\
\hline Shrubs & 4.190 & 0.095 & $*$ \\
\hline Moss & 2.787 & 0.065 & ns \\
\hline Lichen & 0.176 & 0.004 & ns \\
\hline Crust & 2.401 & 0.057 & ns \\
\hline \multicolumn{4}{|l|}{ (c) Root parameter } \\
\hline Root length density $\left(\mathrm{km} \mathrm{m}^{-3}\right)$ & 7.835 & 0.175 & $* *$ \\
\hline RLD (0-0.5 mm) & 3.989 & 0.100 & $(*)$ \\
\hline $\operatorname{RLD}(0.5-1.0 \mathrm{~mm})$ & 5.254 & 0.127 & $*$ \\
\hline RLD $(1.0-1.5 \mathrm{~mm})$ & 1.816 & 0.048 & ns \\
\hline $\operatorname{RLD}(>1.5 \mathrm{~mm})$ & 1.105 & 0.030 & ns \\
\hline Root density $\left(\mathrm{kg} \mathrm{m}^{-3}\right)$ & 11.016 & 0.229 & $* *$ \\
\hline
\end{tabular}

Units are in weight percent (calculated from grams per gram $\times 100$ ) $* * * P<0.001, * * P<0.01, * P<0.05,\left(^{*}\right) P<0.1$, ns $P>0.1$
Aggregate stability was positively correlated with total root length and RLD of very fine roots $(0-0.5 \mathrm{~mm}$, $P<0.1)$ and fine roots $(0.5-1.0 \mathrm{~mm}, P<0.05$, Table 5). However, RLD of fibrous and coarse roots (1.0 $1.5 \mathrm{~mm}$ and $>1.5 \mathrm{~mm}$ ) showed no correlation, indicating that root length in higher diameter classes does not contribute significantly to additional aggregate stability. Of all root parameters, aggregate stability was most strongly correlated with RD (Table 5, Fig. 1). RLD increased with the increasing number of plant species $\left(F_{(1,37)}=6.16, P<0.05\right)$. Elevation had no significant effect on aggregate stability.

Variables explaining the variation in aggregate stability

We partitioned the total variation in aggregate stability to determine the individual and shared effects among three explanatory variables (Table 6). The number of plant species, root density and sand content were chosen according to the best fit regression models for all soil properties, aboveground vegetation characteristics and root parameters (Fig. 1). Among the explanatory variables, the number of plant species was the most relevant factor alone explaining $19 \%$ of the variance in aggregate stability. It explained another $11 \%$ through shared effects with RD and sand content. An additional 8\% was explained through the shared influence of the number of plant species and sand content. Sand content alone explained $9 \%$ of the variation. The combined influence of the three variables explained $54 \%$ of the variance of aggregate stability in the whole model.
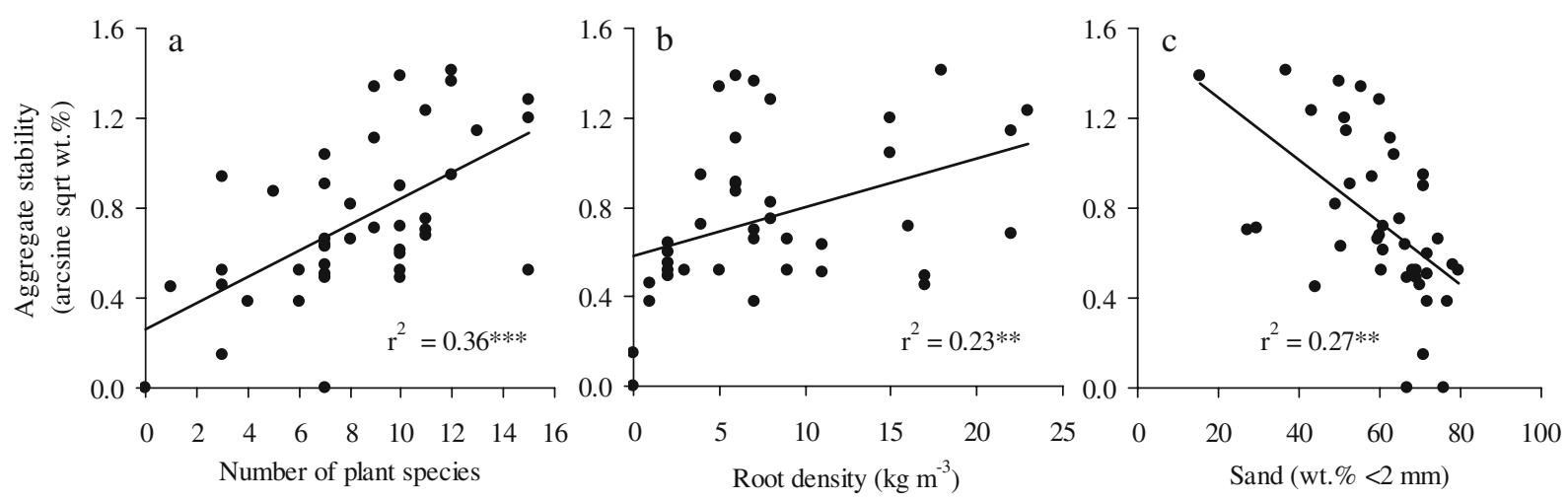

Fig. 1 Relationship between aggregate stability (weight percent, arcsine square root transformed) and a number of plant species, $\mathbf{b}$ root density and $\mathbf{c}$ sand content (weight percent) on ski slopes. ${ }^{* * *} P<0.001,{ }^{*} P<0.01,{ }^{*} P<0.05,\left({ }^{*}\right) P<0.1, n s P>0.1$ 
Table 6 Total sums of squares (ss) quantifying the individual and shared effects of the three explanatory variables species number, sand content and root density as well as an unexplained (error) variation

\begin{tabular}{llr}
\hline Source of variation & Calculation & Total sS (\%) \\
\hline Species number & SS number model 1 & 19.4 \\
Sand content & SS sand model 2 & 8.7 \\
Root density & SS model 1-ss model 3 & 0.4 \\
Shared species number and sand & SS number model 2-ss number model 1 & 8.2 \\
Shared species number and root density & SS number model 3-Ss number model 1 & 2.7 \\
Shared sand and root density & SS sand model 4-ss sand model 2 & 3.2 \\
Shared species number and sand and root density & SS number model 4-SS number model 3-ss number & 11.5 \\
& model 2+ss number model 1 & 54.4 \\
Model $(R)$ & & 45.6 \\
Error & & 100.0 \\
Total & & \\
\hline
\end{tabular}

Results are from the type I sums of squares of four multiple regression models (after Roy et al. 2004): (1) root density, sand content, species number = aggregate stability; (2) root density, species number, sand content = aggregate stability; (3) sand content, species number = aggregate stability; (4) species number, sand content = aggregate stability. See the "Statistical analysis" section for detailed information

\section{Indicator species of higher diversity}

Sixteen out of 70 plant species were significantly more frequent in plots with high plant species richness. The plant species showing the highest correlation $\left(\chi^{2}\right.$-value $)$ with overall species diversity in a given community belonged to three functional groups, such as grasses (Agrostis rupestris and Luzula lutea, $\chi^{2}=19.0$ and 14.0, $P<0.001$ ), forbs (Alchemilla pentaphyllea, Soldanella pusilla and Leontodon helveticus, $\chi^{2}=$ 14.9, 14.0, and 13.6, $P<0.001$ ), and dwarf shrubs (Salix herbacea, $\chi^{2}=13.0, P<0.001$ ).

\section{Discussion}

\section{Abiotic soil properties}

The disturbance on the ski slopes caused changes in soil characteristics, resulting in a higher proportion of bare ground, a higher fraction of gravel and lower soil moisture. During the process of machine-grading, the entire topsoil of a ski slope is usually bulldozed and redistributed. This process is probably responsible for the higher fraction of gravel in the ski slope soils. Gros et al. (2004) also reported the abundance of gravel $(>2 \mathrm{~mm})$ on ski slope soils caused by stone crushing during ski slope establishment. Furthermore, if the ski slope is not re-vegetated effectively after machine-grading, erosion occurs and the fine soil fraction can easily be washed out irreversibly (Barni et al. 2007; Gros et al. 2004). Both mechanisms may be responsible for the coarser soil on the ski slopes in our study. Soil aggregate stability was lower, though not significantly, on ski slopes than in control plots (46.9\% vs. 56.3\%). Gros et al. (2004) reported similar values that ranged between $32.4 \%$ and $46.9 \%$ for restored ski slopes (1 to 13 years old) and $46.5 \%$ for an undisturbed pasture as control.

Above- and below ground vegetation characteristics

The reduction in species numbers and vegetation cover is likely an effect of the vegetation disturbance by the former machine-grading and by snow compaction of the ski slopes in winter. The vegetation and shrub cover were negatively correlated with elevation, which indicates the increasingly difficult re-colonization of such damaged sites by plants (Cammeraat et al. 2005; Chambers 1993; Urbanska 1997; Urbanska and Fattorini 1998; Wipf et al. 2005). Shrub diversity was negatively affected by the disturbance but the diversity of forbs and grasses was not. The woody parts of the shrubs are probably more sensitive to mechanical damage and can more easily break off than the more flexible forbs and grasses. However, although the total cover of forbs and grasses did not differ between ski slopes and control plots, that of specific forb and grass species did. Those plant species that were frequent on ski slopes were characteristic for alpine grasslands (e.g. 
Festuca violacea, Achillea millefolium), whereas plants from control plots were more typical for alpine dwarfshrub heaths (Helictotrichon versicolor, Homogyne alpina). The vegetation changes on ski slopes found in this study are in line with those from previous studies and even more pronounced (Barni et al. 2007; Wipf et al. 2005). In our study, species numbers were decreased by $28 \%$ on ski slopes, while Wipf et al. (2005) reported a decrease in species number by $11 \%$. Furthermore the woody plants were most negatively affected on ski slopes. As all ski slopes in our study are machine-graded, either the initial grading, the compaction during use as a ski slope or, most likely, a combination of the two factors could be responsible for vegetation changes. We found hardly any difference in vegetation between ski slopes with natural snow and those with artificial snow. Potential effects of artificial snow may be masked by the machine-grading of the ski slopes because the grading has more dramatic effects on the vegetation than the use of artificial snow (Wipf et al. 2005).

Root property analysis, which was only carried out on ski slopes and not on adjacent control plots, showed slightly lower root length density of fine roots and higher RLD of fibrous and coarse roots on ski slopes with natural snow. This could have been due to coarser roots of specific forb species, i.e. Leucanthemopsis alpina and Alchemilla pentaphyllea, that were significantly more frequent on slopes with natural snow. The majority of L. alpina roots indeed belongs to a coarser fraction of $>1 \mathrm{~mm}$ (Pohl unpublished data). However, to our knowledge the root morphology of A. pentaphyllea, like those of many other alpine plant species, have not yet been investigated.

Variables influencing aggregate stability on ski slopes

As expected, soil aggregate stability on ski slopes was positively correlated with a large number of abiotic and biotic variables including soil texture, species richness, vegetation cover and root parameters. Soil texture influenced soil aggregate stability, as was expected from common knowledge (Nearing et al. 1991; Tisdall and Oades 1982): fine soil particles (clay and silt) increased and coarser particles (sand and gravel) decreased soil stability. Organic matter, which generally plays a major role in soil aggregation (Chaney and Swift 1984; Scott 1998; Tisdall and Oades 1982), surprisingly showed no relationship with aggregate stability in our study.
Possibly, the type of organic material, i.e. polysaccharides and mycorrhizal hyphae, was more important than the total amount in stabilising the aggregates (Tisdall and Oades 1982). Furthermore, the soils from the studied ski slopes were still too young to show significant effects on soil organic matter formation. Soil moisture, however, was positively correlated with aggregate stability in our study.

All measured vegetation parameters were positively correlated with soil aggregate stability, which underlines the highly positive effect of plants on soils in mountain habitats (Körner and Spehn 2002). Remarkably, species richness showed the strongest relationship with aggregate stability of all vegetation parameters. Most studies have looked at the percentage plant cover as the key factor for soil stability (Bird et al. 2007; Shinjo et al. 1999). Our findings, however, suggest that biodiversity, in addition to plant cover, may play a key role in soil aggregate stability. Nevertheless, it is difficult to separate cause and effect in these correlations. It is hard to say, whether soils with high aggregate stability support more species or vice versa, or whether both reflect the joint succession on those raw soils.

The mechanism by which plant diversity increases the stability of soil aggregates is likely via their root systems. Roots play a key role in soil aggregation, as they transform loose soil particles into stable aggregates by root secretions. Roots not only cause clay particles to re-orientate parallel to the root axis and bind soil particles, they also supply the soil with decomposable organic matter, and they support a large microbial community in the rhizosphere and provide food for soil organisms (Gyssels and Poesen 2003; Tisdall 1994). Miller and Jastrow (1990) pointed out the interaction between root morphology and mycorrhizal fungi. In their conceptual model for the interrelationship between roots, mycorrhizal fungi and water-stable aggregates, the effects of roots are through their fine $(<1 \mathrm{~mm})$ and very fine roots $(<0.5 \mathrm{~mm})$ and through extraradical hyphal length. While this topic was not included in the objectives of our study, we did find that aggregate stability was correlated with the length of fine roots (0.5-1 mm). However, fibrous and coarser roots did not significantly contribute to additional aggregate stability. Thus, we presume that higher root diversity, as a result of higher plant species diversity, had a positive effect on soil aggregate stability. For methodological reasons, we could not assign the roots of our soil samples to specific plant species. However, RLD increased with the 
increasing number of plant species, which further indicates the importance of higher species numbers. The strongest relationship between RLD and aggregate stability, however, was found for fine roots. Additionally, fine roots showed a stronger correlation with aggregate stability than coarse roots. Furthermore, RLD decreased with increasing root diameters, i.e. plants developed more fine than coarse roots. $90 \%$ of roots were very fine $(<0.5 \mathrm{~mm}), 8 \%$ were fine $(0.5$ to $1.0 \mathrm{~mm})$ and only $1 \%$ were fibrous (1.0 to $1.5 \mathrm{~mm})$ and coarse roots $(>1.5$ $\mathrm{mm})$. These results indicate that, despite the apparent importance of different root morphologies, the fine roots were largely responsible for the improvement of soil aggregate stability.

Further support for the importance of different plant-growth forms at high species richness comes from the analysis of single species in our study: those plant species that are frequently associated with more diverse communities (indicator species of high diversity) are not plant functional type specific, hence may belong to either grasses, forbs or shrubs. This means that beneficial effects of high species richness can not only be assigned to one specific functional group, e.g. grasses, but to the combination of several groups. Unfortunately, very little is known about root architecture of alpine plant species so far (but see Kutschera and Sobotik 1997; Polomski and Kuhn 1998).

Variables explaining the variation in aggregate stability

Our multiple regression approach for partitioning the individual and shared effects of the three explanatory variables for aggregate stability demonstrated the high importance of plant species richness. At 19\%, plant species richness explained considerably more of the variation than soil texture or RD. Sand content alone explained $9 \%$ of the variation. An additional $11 \%$ of the variance was explained by shared effects of RD and sand content. This finding demonstrates the key role of plant diversity for soil stability, expressed by the assessment of aggregate stability in our study.

\section{Conclusions}

This study demonstrated the important relationships between plant diversity, root density and soil aggregate stability on disturbed soils in mountain areas. Ski slopes showed negative effects on plant species richness and vegetation cover compared to undisturbed adjacent control sites. However, regression approaches revealed the positive influence of plant diversity, vegetation cover and root density on soil aggregate stability. In subsequent multiple regression and variance partitioning, plant diversity turned out to explain considerably more variance than abiotic soil parameters. The presumed beneficial effect of high plant diversity on soil aggregate stability was probably driven by diverse below-ground growth forms as opposed to uniform vegetation composed of only a few species. We showed that higher aggregate stability was mostly characterised by a higher density of fine roots and, to a lesser extent, of coarse roots. Further, those plant species that were frequently associated with more diverse communities were from different functional groups, i.e. grasses, forbs and shrubs, meaning that beneficial effects can not only be assigned to one specific functional group, but to the combination of several groups. This study supports the view that higher plant diversity is one of the most relevant factors for enhancing soil stability at disturbed sites at high elevation. In high-elevation restoration, it is crucial not only to reestablish a functional vegetation cover with a dense root system, but also to re-create vegetation with a higher number of plant species with different growth forms.

Acknowledgments We would like to thank the Swiss MAVAFoundation and the Swiss Federal Research Institute WSL for the financial support. We thank Nils Peuse for the great assistance in the field, as well as Adrian Käser and Niklaus Hardegger for their valuable laboratory work. Frank Graf, Melissa Martin and the two anonymous referees helped improve this manuscript with useful comments.

\section{References}

Barni E, Freppaz M, Siniscalco C (2007) Interactions between vegetation, roots, and soil stability in restored high-altitude ski runs in the Alps. Arct Antarct Alp Res 39:25-33, doi:10.1657/1523-0430(2007)39[25:IBVRAS]2.0.CO;2

Barthès B, Roose E (2002) Aggregate stability as an indicator of soil susceptibility to runoff and erosion; validation at several levels. Catena 47:133-149, doi:10.1016/S0341-8162(01)00180-1

Bird SB, Herrick JE, Wander MM, Murray L (2007) Multi-scale variability in soil aggregate stability: implications for understanding and predicting semi-arid grassland degradation. Geoderma 140:106-118, doi:10.1016/j.geoderma.2007.03.010

Bisutti I, Hilde I, Raessler M (2004) Determination of total organic carbon - an overview of current methods. TrAC Trends Anal Chem 23:716-726, doi:10.1016/j.trac.2004.09.003 
Borcard D, Legendre P, Drapeau P (1992) Partialling out the spatial component of ecological variation. Ecology 73:1045-1055, doi:10.2307/1940179

Cammeraat E, van Beek R, Kooijman A (2005) Vegetation succession and its consequences for slope stability in SE Spain. Plant Soil 278:135-147, doi:10.1007/s11104-005-5893-1

Chambers JC (1993) Seed and vegetation dynamics in an alpine herb field - effects of disturbance type. Can J Bot 71:471-485

Chaney K, Swift RS (1984) The influence of organic-matter on aggregate stability in some British soils. J Soil Sci 35:223230, doi:10.1111/j.1365-2389.1984.tb00278.x

De Baets S, Poesen J, Gyssels G, Knapen A (2006) Effects of grass roots on the erodibility of topsoils during concentrated flow. Geomorphology 76:54-67, doi:10.1016/j.geomorph. 2005.10.002

De Baets S, Poesen J, Knapen A, Barbera GG, Navarro JA (2007a) Root characteristics of representative Mediterranean plant species and their erosion-reducing potential during concentrated runoff. Plant Soil 294:169-183, doi:10.1007/s11104-007-9244-2

De Baets S, Poesen J, Knapen A, Galindo P (2007b) Impact of root architecture on the erosion-reducing potential of roots during concentrated flow. Earth Surf Process Landf 32:1323-1345, doi:10.1002/esp.1470

Delgado R, Sanchez-Maranon M, Martin-Garcia JM, Aranda V, Serrano-Bernardo F, Rosua JL (2007) Impact of ski pistes on soil properties: a case study from a mountainous area in the Mediterranean region. Soil Use Manage 23:269-277, doi:10.1111/j.1475-2743.2007.00093.x

Frei M, Boll A, Graf F, Heinimann HR, Springmann S (2003) Quantification of the influence of vegetation on soil stability. In: Lee CF, Tham LG (eds) Proceedings of the International Conference on Slope Engineering, Hong Kong, China, pp 872-877

Gee GW, Bauder JW (1986) Particle-size analysis. In: Klute A (ed) Methods of soil analysis. Part 1, physical and mineralogical methods. American Society of Agronomy, Madison, pp 383-411

Gray DH, Sotir RB (1996) Biotechnical and soil bioengineering slope stabilization: a practical guide for erosion control. Wiley, New York

Gros R, Monrozier LJ, Bartoli F, Chotte JL, Faivre P (2004) Relationships between soil physico-chemical properties and microbial activity along a restoration chronosequence of alpine grasslands following ski run construction. Appl Soil Ecol 27:7-22, doi:10.1016/j.apsoil.2004.03.004

Gyssels G, Poesen J (2003) The importance of plant root characteristics in controlling concentrated flow erosion rates. Earth Surf Process Landf 28:371-384, doi:10.1002/ esp. 447

Gyssels G, Poesen J, Bochet E, Li Y (2005) Impact of plant roots on the resistance of soils to erosion by water: a review. Prog Phys Geogr 29:189-217, doi:10.1191/0309133305pp443ra

Isselin-Nondedeu F, Bédécarrats A (2007) Influence of alpine plants growing on steep slopes on sediment trapping and transport by runoff. Catena 71:330-339, doi:10.1016/j. catena.2007.02.001

Kahmen A, Perner J, Buchmann N (2005) Diversity-dependent productivity in semi-natural grasslands following climate perturbations. Funct Ecol 19:594-601, doi:10.1111/j.13652435.2005.01001.x
Körner C, Spehn EM (2002) Mountain biodiversity: a global assessment. Parthenon Publishing Group, London, UK, p 336

Kutschera L, Sobotik M (1997) Bewurzelung von Pflanzen in den verschiedenen Lebensräumen. Landesmuseum, Linz, p 331

Mattia C, Bischetti G, Gentile F (2005) Biotechnical characteristics of root systems of typical Mediterranean species. Plant Soil 278:23-32, doi:10.1007/s11104-005-7930-5

Miller RM, Jastrow JD (1990) Hierarchy of root and mycorrhizal fungal interactions with soil aggregation. Soil Biol Biochem 22:579-584, doi:10.1016/0038-0717(90)90001-G

Nearing MA, Bradford JM, Parker SC (1991) Soil detachment by shallow flow at low slopes. Soil Sci Soc Am J 55:339-344

Niklaus PA, Kandeler E, Leadley PW, Schmid B, Tscherko D, Korner $\mathrm{C}$ (2001) A link between plant diversity, elevated $\mathrm{CO}_{2}$ and soil nitrate. Oecologia 127:540-548, doi:10.1007/s004420000612

Nilaweera NS, Nutalaya P (1999) Role of tree roots in slope stabilisation. Bull Eng Geol Environ 57:337-342, doi:10.1007/s100640050056

Polomski J, Kuhn N (1998) Wurzelsysteme. Haupt, BirmensdorfBern, p 290

Reubens B, Poesen J, Danjon F, Geudens G, Muys B (2007) The role of fine and coarse roots in shallow slope stability and soil erosion control with a focus on root system architecture: a review. Trees - Structure and Function 21:385-402

Rixen C, Stoeckli V, Ammann W (2003) Does artificial snow production affect soil and vegetation of ski pistes? A review. Perspect Plant Ecol 5:219-230, doi:10.1078/14338319-00036

Rixen C, Casteller A, Schweingruber FH, Stoeckli V (2004) Age analysis helps to estimate plant performance on ski pistes. Bot Helv 114:127-138, doi:10.1007/s00035-004-0692-5

Roy BA, Gusewell S, Harte J (2004) Response of plant pathogens and herbivores to a warming experiment. Ecology 85:2570-2581, doi:10.1890/03-0182

Scherer-Lorenzen M, Palmborg C, Prinz A, Schulze ED (2003) The role of plant diversity and composition for nitrate leaching in grasslands. Ecology 84:1539-1552, doi:10.1890/ 0012-9658(2003)084[1539:TROPDA]2.0.CO;2

Scott N (1998) Soil aggregation and organic matter mineralization in forests and grasslands: plant species effects. Soil Sci Soc Am J 62:1081-1089

Shinjo H, Fujita H, Gintzburger G, Kosaki T (1999) Soil aggregate stability under different landscapes and vegetation types in a semiarid area in northeastern Syria. Soil Sci Plant Nutr 46:229-240

Spehn EM, Joshi J, Schmid B, Diemer M, Korner C (2000) Above-ground resource use increases with plant species richness in experimental grassland ecosystems. Funct Ecol 14:326-337, doi:10.1046/j.1365-2435.2000.00437.x

Spehn EM, Hector A, Joshi J, Scherer-Lorenzen M, Schmid B, Bazeley-White E, Beierkuhnlein C, Caldeira MC, Diemer M, Dimitrakopoulos PG, Finn JA, Freitas H, Giller PS, Good J, Harris R, Hogberg P, Huss-Danell K, Jumpponen A, Koricheva J, Leadley PW, Loreau M, Minns A, Mulder CPH, O’Donovan G, Otway SJ, Palmborg C, Pereira JS, Pfisterer AB, Prinz A, Read DJ, Schulze ED, Siamantziouras ASD, Terry AC, Troumbis AY, Woodward FI, Yachi S, Lawton JH (2005) Ecosystem effects of biodiversity manipulations in European grasslands. Ecol Monogr 75:37-63, doi:10.1890/ 03-4101 
Tisdall JM (1994) Possible role of soil-microorganisms in aggregation in soils. Plant Soil 159:115-121

Tisdall JM, Oades JM (1982) Organic-matter and water-stable aggregates in soils. J Soil Sci 33:141-163, doi:10.1111/ j.1365-2389.1982.tb01755.x

Urbanska KM (1995) Biodiversity assessment in ecological restoration above the timberline. Biodivers Conserv 4:679-695, doi:10.1007/BF00158862

Urbanska KM (1997) Restoration ecology research above the timberline: colonization of safety islands on a machinegraded alpine ski run. Biodivers Conserv 6:1655-1670, doi:10.1023/A:1018382923596
Urbanska KM, Fattorini M (1998) Seed bank studies in the Swiss Alps. I. Un-restored ski run and the adjacent intact grassland at high elevation. Bot Helv 108:93-104

Van Ommeren RJ (2001) Species composition on reclaimed ski runs compared with unseeded areas. J Range Manag 54:307-311, doi:10.2307/4003252

Wipf S, Rixen C, Fischer M, Schmid B, Stoeckli V (2005) Effects of ski piste preparation on alpine vegetation. J Appl Ecol 42:306-316, doi:10.1111/j.1365-2664.2005.01011.x

Zuazo VHD, Pleguezuelo CRR (2008) Soil-erosion and runoff prevention by plant covers, A review. Agronomy for Sustainable Development 28:65-86, doi:10.1051/agro:2007062 